\title{
PENERAPAN HUKUM HAK CIPTA SENI BATIK PEKALONGAN SEBAGAI KOMODITAS INTERNASIONAL (STUDI UPAYA PEMERINTAH KOTA PEKALONGAN MENJADIKAN BATIK PEKALONGAN SEBAGAI KOMODITAS INTERNASIONAL)
}

\author{
NUR ENDANG TRIMARGAWATI, SH.
}

\begin{abstract}
ABSTRAK
Batik sebagai warisan budaya Indonesia yang dibuat secara konvensional perlu dilindungi dan dipertahankan. Hal yang paling mendasar dalam upaya melestarikan seni batik, batik kontemporer dan khususnya batik tradisional adalah upaya memberikan penghargaan berupa perlindungan bagi para pembatik atas hasil karya intelektualnya. Perlindungan bagi karya seni batik dapat diberikan melalui Undang-Undang Nomor 19 Tahun 2002 tentang Hak Cipta.

Batik Pekalongan sebagai karya seni dan warisan budaya sangat dikagumi dunia, karena kaya akan corak dan warnanya, dan para pembatiknya selalu mengikuti perkembangan jaman.. Batik Pekalongan sebagai komoditas internasional harus terus ditingkatkan agar bisa terus bersaing dalam globalisasi perdagangan. Batik sebagai karya cipta yang diperdagangkan harus didaftarkan ke Direktorat Jenderal Hak Kekayaan Intelektual, dan yang bisa didaftarkan adalah merek, corak atau teknologinya. Namun faktanya, masih banyak perusahaan batik Pekalongan yang tidak mendaftarkan karya seni batiknya, karena masyarakat pengrajin batik masih kurang memahami Undang-undang Hak Cipta, selain itu pula masih adanya pelanggaran hak cipta atas seni batik.

Berdasarkan latar belakang tersebut, maka dapat dirumuskan permasalahan sebagai berikut: (1) Bagaimanakah penerapan hukum hak cipta pada seni batik kontemporer dan seni batik tradisional Pekalongan sebagai komoditas internasional? dan (2) Bagaimanakah upaya-upaya Pemerintah Kota Pekalongan menjadikan batik Pekalongan sebagai komoditas internasional?

Metode penelitian yang digunakan adalah metode pendekatan yuridis sosiologis dengan analisa secara kualitatif. Metode pengumpulan data diperoleh melalui data primer dan data sekunder.

Hasil penelitian adalah bahwa seni batik di Indonesia mulai mendapat perlindungan Hak Cipta sejak UUHC 1987 hingga UUHC 2002. Menurut UUHC 1987 dan UUHC 1997, seni batik yang mendapat perlindungan adalah seni batik yang bukan tradisional dengan pertimbangan batik yang tradisional telah menjadi milik bersama, sehingga konsekuensinya bagi orang Indoonesia mempunyai kebebasan untuk menggunakannya tanpa dianggap sebagai suatu pelanggaran. Sedangkan UUHC 2002, unsur yang ditekankan adalah pada pembuatan batik secara konvensional. Seni batik mendapat perlindungan hukum karena termasuk dalam lingkup Hak Cipta menurut ketentuan Pasal 12 UUHC 2002. dan untuk ciptaan batik tradisional yang termasuk folklor dilindungi oleh Pasal 10.
\end{abstract}


Upaya-upaya Pemerintah Kota Pekalongan menjadikan batik Pekalongan sebagai komoditas internasional adalah sebagai berikut: (1) mengembangkan potensi batik dengan formulasi yang lebih fokus dan terkonsentrasi melalui pendekatan kluster industri (sentra produksi dan sentra perdagangan), (2) Klinik Bisnis dan HKI, (3) Musium Batik Pekalongan, (4) mengusahakan pemberian kredit lunak kepada pengrajin, (5) peningkatan SDM terutama untuk pengrajin dengan kursus-kursus pelatihan, (6) peresmian trading house UKMK Kota Pekalongan, (7) pembangunan sentra-sentra grosir, dan lain-lain.

Kata Kunci : Batik Pekalongan, Komoditas Internasional, Hukum Hak Cipta

\section{A. PENDAHULUAN}

\section{LATAR BELAKANG MASALAH}

Batik merupakan karya seni dan budaya warisan leluhur bangsa Indonesia yang dikagumi dunia. Batik telah menjadikan Indonesia sebagai salah satu negara terkemuka penghasil kain tradisional yang halus di dunia. Julukan ini datang dari suatu tradisi yang cukup lama berakar di bumi Indonesia, sebuah sikap adati yang sangat kaya, beraneka ragam, kreatif, serta artistik. Salah satu daerah yang dijuluki sebagai Kampoeng Batik Indonesia adalah Pekalongan. Hal tersebut dengan adanya tiga ikon sebagai tempat mempromosikan batik antara lain Museum Batik di Jalan Jetayu, Pasar Grosir Sentono, dan Kampoeng Batik Kauman yang telah memperkuat pencitraan Pekalongan identik dengan batik. ${ }^{1}$

Batik Pekalongan bukan hanya terkenal di dalam negeri, tetapi juga terkenal di mancanegara. Kepopuleran batik dari Pekalongan Jawa Tengah ini telah menjadikan seni batik ini tidak berhenti sebagai hasil kegiatan ekonomi dan komoditas internasional, tetapi juga menjadi ikon wisata. ${ }^{2}$

Ragam corak dan warna batik dipengaruhi oleh berbagai pengaruh asing. ${ }^{3}$ Batik Pekalongan termasuk batik pesisir yang paling kaya akan warna. Sebagaimana ciri khas batik pesisir, ragam hiasnya bersifat

1 Purwadi, Trias, Museum, Pasar Grosir dan Kampoeng Batik, Suara Merdeka, 1 September 2007.

2 www.kompas.com ,"Batik Pekalongan, antara Masa Lampau dan Kini”.

3 Purba, Afrillyanna, TRIPs-WTO dan Hukum HKI Indonesia Kajian Perlindungan Hak Cipta Seni Batik Tradisional Indonesia, (Jakarta: Rineka Cipta, 2005), halaman 60-62. 
naturalis. Apabila dibandingkan dengan batik pesisir lainnya, batik Pekalongan ini sangat dipengaruhi pendatang keturunan Cina dan Belanda. Motif batik Pekalongan sangat bebas dan menarik, meskipun motifnya terkadang sama dengan batik Solo atau Yogyakarta, seringkali dimodifikasi dengan variasi warna yang sangat atraktif. Tak jarang pada sehelai kain batik dijumpai ada delapan warna yang berani dengan kombinasi yang dinamis. Motif tradisional yang paling populer dan terkenal di Pekalongan adalah motif batik "Jlamprang". 4 Keistimewaan batik Pekalongan adalah para pembatiknya selalu mengikuti perkembangan jaman. Masyarakat Pekalongan memang tidak pernah kehabisan ide untuk membuat kreasi motif batik. ${ }^{5}$

Batik Pekalongan sebagai warisan budaya merupakan ciptaan khas bangsa Indonesia yang dibuat secara kontemporer perlu dilindungi dan dipertahankan. Hal yang paling mendasar dalam upaya melestarikan seni batik khususnya batik tradisional adalah upaya memberikan penghargaan berupa perlindungan bagi para pembatik atas hasil karya intelektualnya melalui karya seni batik. Perlindungan bagi karya seni batik ini dapat diberikan melalui hak cipta. Hal ini penting karena dalam proses menghasilkan suatu karya seni batik diperlukan sejumlah pengorbanan baik pikiran, tenaga, biaya dan waktu. ${ }^{6}$

Batik sebagai komoditas internasional harus terus ditingkatkan. Agar bisa terus bersaing dalam globalisasi perdagangan, baik di dalam negeri maupun untuk keperluan ekspor, sejak dahulu Pemerintah Kota Pekalongan telah menetapkan bahwa semua batik yang dipasarkan harus memakai merek dan label, untuk melindungi kepentingan baik produsen maupun konsumen, sehingga konsumen yang bukan ahli dalam masalah batik, tidak akan salah pilih. Begitu pula bagi produsen batik, terutama pengusaha kecil yang umumnya pengrajin batik tradisional, diharapkan

4 Djoemena, Nian S., Ungkapan Sehelai Batik (Its Mystery and Meaning), (Jakarta: Djambatan, 1986), halaman 12.

5 www.compas.com, Loc.Cit.

6 Purba, Afrillyanna, dkk, Op.Cit., halaman 7. 
dapat dilindungi dari ulah para pembajak yang biasanya bermodal lebih besar dan kuat. ${ }^{7}$

Festival Batik Indonesia 2003 dan 2005 dan Pekan Batik Internasional 2007 yang diselenggarakan oleh Pemerintah Kota Pekalongan sebagai momentum yang membangun kesadaran kolektif untuk mengikhtiarkan penduniaan batik serta menjadikan batik sebagai komoditas internasional. Hal tersebut dikarenakan ada kemauan kuat untuk mengkukuhkannya menjadi pusat batik bukan hanya nasional tetapi juga mendunia. Kegiatan internasional itu mempunyai makna strategis terkait dengan dinamika perdagangan dunia dewasa ini. Globalisasi pada sisi lain berbias ke arah upaya menggali kekuatan-kekuatan lokal untuk bersaing di pasar bebas. Makin unik suatu produk atau karya, makin tinggi pula distingsi untuk bersaing dengan keunggulan kompetitifnya. ${ }^{8}$

Batik dianggap warisan budaya dan karya cipta yang diperdagangkan. Sebagai produk dagang batik harus didaftarkan di Ditjen Hak Kekayaan Intelektual. Yang didaftarkan bisa merek, corak atau teknologinya dan harus dibedakan batik sebagai produk dagang dan batik sebagai warisan budaya. Faktanya masih banyak perusahaan batik yang tidak mendaftarkan karya seni batiknya ke Ditjen HKI. Hanya perusahaan batik yang tergolong besar saja yang mendaftarkan karya cipta seni batiknya, mereka hanya mendaftarkan beberapa motif saja yaitu motif yang bersifat jangka panjang dan motif yang dibuat berdasarkan kontrak pesanan. Oleh karena ruwetnya, perlu sosialisasi warisan budaya yang mana saja harus didaftarkan ke Direktorat Jenderal Hak Kekayaan Intelektual Departemen Hukum dan Hak Asasi Manusia Republik Indonesia. $^{9}$

Seni batik merupakan salah satu sumber dari karya intelektual yang dapat dan perlu dilindungi oleh undang-undang Hak Cipta. Seni batik itu tidak semata-mata untuk kepentingan seni dan budaya itu sendiri, tetapi

Ibid, halaman 6.

Purwadi, Trias, Menduniakan Batik Lewat Pekalongan, Suara Merdeka, 3 September 2007.

Purba, Achmad Zen Umar, Jembatan Budaya Serumpun, Artikel, Tempo, 18 November 2007. 
dapat dimanfaatkan untuk meningkatkan kemampuan di bidang perdagangan dan industri. Pasal 12 ayat (1) huruf (i) Undang-undang Nomor 19 Tahun 2002 Tentang Hak Cipta menetapkan bahwa "Dalam Undang-undang ini ciptaan yang dilindungi adalah ciptaan dalam bidang ilmu pengetahuan, seni dan sastra yang didalamnya mencakup seni batik.

Seni batik sebagai suatu kebudayaan tradisional yang telah berlangsung secara turun-temurun, maka hak cipta atas seni batik ini akan dipegang oleh Negara sebagaimana diatur dalam Pasal 10 ayat (2) Undang-undang Nomor 19 Tahun 2002 Tentang Hak Cipta, yaitu: "Negara memegang Hak Cipta atas folklor dan hasil kebudayaan rakyat yang menjadi milik bersama, seperti cerita, hikayat, dongeng, legenda, babad, lagu, kerajinan tangan, koreografi, tarian, kaligrafi, dan karya seni lainnya.

\section{PERMASALAHAN}

Dari uraian di atas dan sesuai dengan judul tesis yaitu "Penerapan Hukum Hak Cipta Seni Batik Pekalongan sebagai Komoditas Internasional (Studi Upaya Pemerintah Kota Pekalongan Menjadikan Batik Pekalongan sebagai Komoditas Internasional)”, penulis membatasi permasalahan yaitu sebagai berikut:

1. Bagaimanakah penerapan Hukum Hak Cipta pada Seni Batik Kontemporer dan Seni Batik Tradisional Pekalongan sebagai komoditas internasional?

2. Bagaimanakah upaya-upaya Pemerintah Kota Pekalongan menjadikan Batik Pekalongan sebagai komoditas internasional?

\section{TUJUAN DAN KONTRIBUSI PENELITIAN}

\section{a. Tujuan Penelitian}

Secara umum penelitian ini bertujuan untuk menemukan dan menjelaskan Penerapan Hukum Hak Cipta Seni Batik Pekalongan sebagai Komoditas Internasional. Tujuan umum bahwa masyarakat, terutama yang menghasilkan suatu karya cipta masih kurang 
memahami Undang-undang Hak Cipta serta masih adanya pelanggaran hak cipta mengenai batik. Dari tujuan tersebut diharapkan hasilnya dapat digunakan untuk mengetahui dan menganalisis;

1. Penerapan Hukum Hak Cipta pada Seni Batik Kontemporer dan Seni Batik Tradisional Pekalongan sebagai Komoditas Internasional.

2. Upaya-upaya Pemerintah Kota Pekalongan menjadikan Batik Pekalongan sebagai komoditas internasional.

\section{b. Kontribusi Penelitian}

Apabila tujuan sebagaimana dirumuskan di atas tercapai, maka diharapkan hasil penelitian akan memberikan dua kegunaan sekaligus, yaitu:

1. Aspek keilmuan, di mana penelitian ini diharapkan dapat memberikan kontribusi bagi perbendaharaan konsep, metode atau pengembangan teori.

2. Aspek praktis, meskipun tidak dimaksudkan untuk solusi bagi para biokrat, hasil penelitian ini dapat digunakan sebagai sarana informasi awal bagi para peneliti yang hendak meneliti bidang kajian yang sama maupun bagi para perencana dan pelaksana hukum sesuai dengan konsep yang diemban masing-masing.

\section{TINJAUAN PUSTAKA}

\section{A. HAK CIPTA PADA UMUMNYA}

\section{Sejarah Pengaturan Hak Cipta}

Hak Cipta diundangkan sejak zaman Belanda yaitu melalui Auters Wet Tahun 1912 Staatsblad No.600, pada mulanya merupakan perlindungan hukum yang diberikan pada seorang pengarang. ${ }^{10}$

10 Suhardo, Etty S., Implikasi Undang-Undang No.19 Tahun 2002 bagi Pengguna Hak Cipta , Makalah disampaikan pada Seminar Nasional menyikapi Problematika Hak Cipta dalam Dunia Usaha: Implementasi Undang-Undang Nomor 19 Tahun 2002, diselenggarakan oleh Fakultas Hukum Universitas Semarang, 11 Desember 2003, halaman 3. 
Pengaturan hukum nasional mengenai Hak Cipta sebagai berikut:

a. Undang-undang Nomor 6 Tahun 1982 tentang Hak Cipta;

b. Undang-undang Nomor 7 Tahun 1987;

c. Undang-undang Nomor 12 Tahun 1997; dan

d. Undang-undang Nomor 19 Tahun 2002.

Pengaturan hukum internasional mengenai hak cipta antara lain:

1) Konvensi Bern 1886;

2) Konvensi Hak Cipta Universal 1955;

3) Konvensi Roma 1961;

4) Konvensi Jenewa 1971;

5) Konvensi Brussel 1974;

6) Perjanjian Umum mengenai Tarif dan Perdagangan (GATT) yang dikaitkan dengan TRIPs 1994;

7) WIPO Copyright Treaty (WCT) Tahun 1996 diratifikasi Indonesia dengan Keputusan Presiden Nomor 19 Tahun 1997.

6) WIPO Performances and Phonograms Treaty (WPPT) Tahun 1996, diratifikasi Indonesia dengan Keputusan Presiden Nomor 74 Tahun 2004. ${ }^{11}$

\section{Pengertian Hak Cipta}

Pada beberapa negara definisi Hak Cipta tidak ada yang sama, namun dalam pengertian yang ada terdapat kesamaan yakni Hak Cipta sebagai Hak Khusus bagi pencipta maupun penerima hak pada bidang karya seni dan sastra .

\section{World Intellectual Property Organization (WIPO)} memberikan pengertian tentang Hak Cipta sebagai berikut :

"Hak Cipta adalah terminologi hukum yang menggambarkan hakhak yang diberikan pada pencipta untuk karya-karya mereka dalam bidang seni dan sastra."

11 Usman, Rachmadi, Hukum Hak atas Kekayaan Intelektual "Perlindungan dan Dimensi Hukumnya di Indonesia", (Bandung: Alumni, 2003), halaman 14-15, 
Pasal 1 Austersweet 1912 menyebutkan:

"Hak Cipta adalah hak tunggal daripada pencipta, atau hak dari yang mendapatkan hak tersebut atas hasil ciptaanya dalam lapangan kesusasteraan, pengetahuan dan kesenian, untuk mengumumkan dan memperbanyak dengan mengingat pembatasan-pembatasan yang ditentukan undang-undang."

Pasal V Universal Copyright Convention menyatakan:

"Hak cipta meliputi hak tunggal si pencipta untuk membuat, menerbitkan dan memberi kuasa untuk membuat terjemahan dari karya yang dilindungi perjanjian ini."

Undang-Undang No. 19 Tahun 2002 Tentang Hak Cipta pengertian hak cipta dapat dilihat dalam Pasal 1 Ayat (1) yang menyebutkan bahwa :

"Hak eksklusif bagi pencipta atau penerima hak untuk mengumumkan atau memperbanyak ciptaannya atau memberikan izin untuk itu dengan tidak mengurangi pembatasan-pembatasan menurut peraturan perundang-undangan yang berlaku."

Berdasarkan pada ketentuan-ketentuan di atas, maka hak cipta dapat didefinisikan sebagai suatu hak monopoli untuk memperbanyak atau mengumumkan ciptaan yang dimiliki oleh pencipta atau pemegang hak cipta lainnya yang dalam implementasinya memperhatikan pada peraturan perundangundangan yang berlaku.

\section{Prinsip-prinsip Dasar Hak Cipta}

a. Yang dilindungi hak cipta adalah ide yang telah berwujud dan asli.

b. Hak cipta timbul dengan sendirinya (otomatis).

c. Suatu ciptaan tidak perlu diumumkan untuk memperoleh hak cipta.

d. Hak cipta suatu ciptaan merupakan suatu hak yang diakui hukum (legal right) yang harus dipisahkan dan harus dibedakan dari penguasaan fisik suatu ciptaan. 
e. Hak cipta bukan hak mutlak (absolut). ${ }^{12}$

\section{Ruang Lingkup Hak Cipta}

Menurut ketentuan Pasal 12 Undang-Undang Hak Cipta, ciptaan yang dilindungi itu terdiri dari:

a. Buku, program komputer, pamflet, perwajahan (lay out) karya tulis yang diterbitkan, dan semua hasil karya tulis lain.

b. Ceramah, kuliah, pidato, dan ciptaan lain yang sejenis dengan itu.

c. Alat peraga yang digunakan untuk kepentingan pendidikan dan ilmu pengetahuan.

d. Lagu atau musik dengan atau tanpa teks.

e. Drama atau drama musical, tari, koreografi atau pewayangan, dan pantomim.

f. Seni rupa dengan segala bentuk seperti seni lukis, gambar, seni ukir, seni kaligrafi, seni pahat, seni patung, kolase, dan seni terapan.

g. Arsitektur.

h. Peta.

i. Seni batik.

j. Fotografi.

k. Sinematografi.

1. Terjemahan, tafsir, saduran, bunga rampai, database, dan karya lain dari hasil pengalihwujudan.

Di samping ciptaan di bawah yang dilindungi ada lagi beberapa ciptaan yang dilindungi oleh Undang-Undang Hak Cipta, sebagaimana dituangkan dalam ketentuan Pasal 10 ayat (1) dan (2)

Undang-Undang Hak Cipta yang menyatakan:

a. Negara memegang hak cipta atas karya peninggalan prasejarah, sejarah dan benda budaya nasional lainnya.

b. Negara memegang hak cipta atas folklor dan hasil kebudayaan rakyat yang menjadikan milik bersama seperti cerita, hikayat, dongeng, legenda, babad, lagu, kerajinan tangan, koreografi,

\section{Folklor} tarian, kaligrafi dan karya seni lainnya.

Pasal 10 UUHC No.19 Tahun 2002 yang berjudul "Hak Cipta atas ciptaan yang penciptanya tidak diketahui”, menetapkan:

\footnotetext{
${ }^{12}$ Ibid, halaman 8-10.
} 
a. Negara memegang hak cipta atas karya peninggalan prasejarah, sejarah dan benda nasional lainnya;

b. Negara memegang hak cipta atas folklore dan hasil kebudayaan rakyat yang manjadi milik bersam, seperti: cerita, hikayat, dongeng, legenda, babad, lagu, kerajinan tangan, koreografi, tarian, kaligrafi, dan karya seni lainnya;

c. Untuk mengumumkan atau memperbanyak ciptaan tersebut pada ayat (2), orang yang bukan warga negara Indonesia harus terlebih dahulu mendapat ijin dari instansi terkait dalam masalah tersebut;

d. Ketentuan lebih lanjut mengenai hak cipta yang dipegang oleh negara sebagaimana dimaksud dalam pasal ini diatur dengan peraturan pemerintah.

Hak cipta atas folklore dan hasil kebudayaan rakyat yang menjadi milik bersama, perlindungannya berlaku tanpa batas waktu (Pasal 31 Ayat 1a). Pasal ini jelas bertujuan melindungi karyakarya tradisional.

\section{Jangka Waktu Perlindungan Hak Cipta}

Berdasarkan Pasal 29 ayat (1) UUHC 2002, terhadap ciptaan-ciptaan yang orisinil, jangka waktu perlindungan hak cipta adalah selama hidup pencipta dan terus berlangsung hingga 50 tahun setelah pencipta meninggal dunia. Untuk ciptaan-ciptaan berdasarkan Pasal tersebut, yang dimiliki oleh dua orang atau lebih, hak cipta berlaku selama hidup pencipta yang meninggal dunia paling akhir dan berlangsung hingga 50 tahun sesudahnya.

Pasal 30 UUHC 2002 mengatur tentang jangka waktu perlindungan hak cipta terhadap ciptaan-ciptaan derivatif, dan Pasal 31 UUHC 2002 mengatur tentang jangka waktu perlindungan hak cipta atas ciptaan yang dipegang dan dilaksanakan oleh negara dan hak cipta atas ciptaan yang dilaksanakan oleh penerbit.

\section{Pendaftaran Hak Cipta}

Pendaftaran ciptaan sesuai dengan Pasal 35 ayat (4) Undang-Undang Hak Cipta tidak merupakan kewajiban bagi pencipta karena hak cipta itu ada setelah ciptaan tersebut dituangkan dalam bentuk yang nyata, tetapi Surat Pendaftaran Hak 
Cipta yang diperoleh bagi pencipta datau pemegang hak cipta dapat dijadikan sebagai alat bukti awal apabila di kemudian hari terjadi permasalahan hukum bagi pencipta atau pemegang hak cipta.

\section{B. SENI BATIK INDONESIA}

\section{Jenis-jenis Batik}

Kain batik dibedakan menjadi dua macam berdasarkan pengertian batik tradisional dan modern, yaitu:
a. Batik Tulis
b. Batik Modern
1) Batik Cap
2) Batik Kombinasi
c. Tekstil Motif Batik ${ }^{13}$

\section{Motif-motif Batik}

Suatu ragam hias sangat dipengaruhi dan erat hubungannya dengan faktor-faktor:

a. letak geografis daerah pembuat batik yang bersangkutan;

b. sifat dan tata penghidupan daerah yang bersangkutan;

c. kepercayaan dan adat istiadat yang ada di daerah yang bersangkutan;

d. keadaan alam sekitarnya, termasuk flora dan fauna; dan

e. adanya kontak atau hubungan antar daerah pembatikan. ${ }^{14}$

Berdasarkan perkembangan batik di pulau Jawa, pola batik dapat dirinci menjadi 3 unsur pokok, yakni ragam hias utama (klowongan), isen-isen dan ragam hias pengisi. Ragam hias utama (klowongan) adalah bentuk hiasan yang menjadi unsur penyusun utama pola batik. $^{15}$

Berdasarkan bentuknya, pola batik terbagi atas dua kelompok besar, yakni:

\footnotetext{
Purba, Affrilyana, halaman 50-51.

Ibid, halaman 54.

Ibid, halaman 55-56.
} 
a. pola batik berulang atau pola geometri

1) Pola ceplok atau garis silang;

2) Pola parang;

3) Pola lereng.

b. Pola Non Geometri

1) Pola semen;

2) Pola lung-lungan;

3) Pola buketan. ${ }^{16}$

Berdasarkan gayanya, ada dua jenis pola batik, yakni batik pedalaman dan batik pesisir. Batik pedalaman merupakan batik yang berasal dari keraton dan batik yang mendapat pengaruh sangat kuat dari keraton, baik ragam hias maupun warnanya. Ragam hias batik pedalaman bersifat simbolis berlatarkan kebudayaan Hindu-Jawa dengan warna sogan, indigo (biru), hitam dan putih.

Batik pesisir mempunyai ragam hias dan warna yang mengandung unsur-unsur budaya dari luar. Ragam hiasanya bersifat naturalis dengan warna yang beraneka ragam. ${ }^{17}$

\section{Perlindungan Hukum pada Seni Batik}

Penguatan perlindungan atas seni batik Indonesia melalui Hak Cipta sudah mulai digalakkan. Hal ini berawal dari kasus pembajakan oleh Malaysia. Pemerintah Indonesia bereaksi dengan mendata berbagai corak batik khas Indonesia lalu mendaftarkannya ke Direktorat Jenderal Hak Kekayaan Intelektual di Tangerang. Kini, puluhan corak batik asal Indonesia telah "diamankan" melalui perlindungan Hak Cipta, termasuk batik asal Pekalongan.

a. Milik bersama

Hukum Hak Cipta nasional sekarang telah melakukan terobosan dengan memungkinkan pemerintah mengambil alih

${ }^{16} \underline{\mathrm{Ibid}}$, halaman 56-60.

${ }^{17}$ Ibid, halaman 60-62. 
pengelolaan hak untuk kepentingan pencipta yang tidak diketahui identitasnya, jangka waktu perlindungannya juga rawan perdebatan.

Alhasil, batik Pekalongan, angklung sunda, "Rasa Sayange", dan reog ponorogo, jika tampil murni sebagai karya tradisional tanpa "sentuhan baru" dari individu yang masih hidup, juga adalah kekayaan tradisional yang sudah jadi milik bersama. Inilah yang membuat perlindungan Hak Cipta yang kini berlaku bisa saja bicara, tetapi tidak banyak.

b. Hak Moral

Hak Cipta juga meliputi Hak Moral. Hak Moral tercantum dalam Konvensi Bern dengan Malaysia dan Indonesia terikat di dalamnya. Hak Moral bukan hak ekonomi, tetapi ada untuk melindungi integritas ciptaan serta hak pencipta untuk tetap dicantumkan namanya, sekalipun ia sudah tidak lagi memiliki hak untuk menerima keuntungan ekonomi dari ciptaannya.

c. Hak atas Indikasi Asal

Potensi perlindungan lain yang ditawarkan hukum, yakni perlindungan terhadap tanda, nama atau indikasi asal suatu barang, yang disebut perlindungan Indikasi Asal. Perlindungan ini terdapat dalam Perjanjian Paris untuk Perlindungan Hak Kekayaan Industrial 1883 (The Paris Convention for Protection of Industrial Property of 1883). Perjanjian Paris melarang setiap barang beredar dengan menggunakan Indikasi Asal yang salah atau menyesatkan.

Dalam hukum nasional Indonesia, Indikasi Asal sebetulnya juga telah diatur. Sayangnya, pengaturannya hanya merupakan bagian kecil dari UU No. 15 Tahun 2001 tentang Merek. Itu membuat penafsiran umum yang sempit di kalangan pakar hukum nasional, jika ada pembicaraan soal Indikasi Asal, pasti yang 
dibicarakan "hanyalah" sejenis merek dagang seperti Nike, Channel atau Prada.

Indikasi Asal diartikan sebagai bagian dari Indikasi Geografis dalam arti luas, hanya saja belum didaftar, sejarah dan akar budaya setempat, termasuk tradisi pembuatannya, justru adalah salah satu syarat utama perlindungan, di samping faktor alamiah lainnya.

d. Hak Kebudayaan

Kekayaan tradisional juga merupakan Hak Kebudayaan. Menurut Kovenan Internasional Hak Ekonomi, Sosial, dan Budaya yang telah diratifikasi Indonesia, Hak Kebudayaan adalah Hak Asasi. Hak Kekayaan Intelektual bisa dikatakan sebagai bagian dari Hak Kebudayaan karena kesamaan objek. Apalagi, jika objek itu juga sudah jelas terkait dengan Hak Atas Identitas, yakni sebagai salah satu faktor penentu identitas kultural. Menariknya, penegakan Hak Kebudayaan sebagai hak kolektif menuntut peran aktif pemerintah.

\section{Perlindungan Hukum Nasional Terhadap Seni Batik Indonesia}

Seni batik di Indonesia mulai mendapat perlindungan hak cipta sejak UUHC 1987 hingga UUHC 2002. Berdasarkan ketentuan UUHC 1987 dan 1997, seni batik yang mendapat perlindungan hak cipta adalah seni batik yang bukan tradisional dengan pertimbangan bahwa seni batik yang tradisional telah menjadi milik bersama (public domein). Konsekuensinya bagi orang Indonesia mempunyai kebebasan untuk menggunakannya tanpa dianggap sebagai suatu pelanggaran. Pada UUHC 2002, unsur yang ditekankan adalah pada "pembuatan batik secara 
kontemporer". Adapun batik yang dianggap paling baik dan paling tradisional/kontemporer adalah batik tulis. ${ }^{18}$

\section{METODE PENELITIAN}

\section{Metode Pendekatan}

Metode pendekatan yang digunakan dalam penelitian ini adalah metode pendekatan yuridis normatif atau metode pendekatan hukum doktrinal yaitu pendekatan secara ilmu hukum dengan menggunakan metode dogmatis hukum atau mempergunakan sumber data sekunder ${ }^{19}$, sehingga disamping terjamin kepastian hukum, juga pemecahan masalah yang menyangkut penerapan Hukum Hak Cipta Seni Batik Pekalongan sebagai Komoditas Internasional. ${ }^{20}$

\section{Spesifikasi Penelitian}

Dalam penyusunan dan penulisan tesis ini akan dipergunakan salah satu spesifikasi penelitian yaitu deskriptif analitis. Bersifat deskriptif analitis karena penelitian ini dimaksudkan untuk memberikan gambaran secara rinci, sistematis dan menyeluruh mengenai segala sesuatu baik perundang-undangan maupun teori-teori hukum. ${ }^{21}$ Tesis ini tentang pelaksanan hukum positif yang menyangkut masalah penerapan Hukum Hak Cipta Seni Batik Pekalongan sebagai komoditas internasional.

\section{Sampel Penelitian}

Penelitian dilakukan terhadap mereka yang terpilih menjadi responden secara purposive sampling, ${ }^{22}$ maka yang menjadi sample dalam penelitian ini adalah sebagai berikut:

18 Ismunandar, R.M., Teknik dan Mutu Batik Tradisional-Mancanegara, (Semarang: Dahara Prize, 1985), halaman 17-18.

19 Soemitro, Ronny Hanitijo, Metodologi Penelitian Hukum dan Jurimetri, (Jakarta : Ghalia Indonesia, 1983), halaman 10 .

20 Ibid, halaman 22.

21 Ibid, halaman 97.

22 Loc. Cit. 

a. Kepala Pemerintah Kota Pekalongan;
b. Kepala Dinas Perindustrian dan Perdagangan Pekalongan;
c. Kepala Dinas Pariwisata dan Kebudayaan Pekalongan.
d. Kepala Musium Batik Pekalongan.

\section{Jenis dan Sumber Data}

Penelitian ini menggunakan dua jenis data kualitatif yaitu data primer dan data sekunder. Data primer adalah data yang diperoleh melalui survey lapangan sedangkan data sekunder ini adalah data yang bersumber dari penelitian kepustakaan. ${ }^{23}$.

\section{Metode Pengumpulan Data}

Untuk mengklasifikasikan data primer, pengumpulan data dilakukan dengan dua cara yaitu pengamatan (observasi) dan wawancara. $^{24}$ Dan dalam hal pengumpulan data sekunder dilakukan melalui studi pustaka yaitu terhadap berbagai dokumen dan bahanbahan pustaka yang berkaitan dengan pemasalahan yang diteliti. ${ }^{25}$

\section{Analisis Data}

Di dalam pembahasan tesis ini, penulis menggunakan metode analisis kualitatif yaitu analisis data yang bertitik tolak pada usahausaha penemuan asas-asas dan informasi-informasi yang bersumber dari responden. Dan cara berpikir untuk mengambil kesimpulan dari penelitian yang dilakukan penulis dengan menggunakan metode induktif.. $^{26}$

\section{B. HASIL PENELITIAN DAN PEMBAHASAN}

\section{Penerapan Hukum Hak Cipta pada Seni Batik Kontemporer dan Seni} Batik Tradisional Pekalongan sebagai komoditas internasional

23 Soemitro, Ronny Hanitijo, Op.Cit., halaman 52.

24 S. Nasution dan M. Thomas, Buku Penuntun Membuat Tesis, Skripsi, Disertasi, dan Makalah, (Bandung: Jemmars, 1988), halaman 58.

25 Soemitro, Ronny Hanitijo,Op.Cit., halaman 57.

26 Ibid, halaman 106. 
Seni batik di Indonesia mulai mendapat perlindungan hak cipta sejak UUHC 1987 hingga UUHC 2002. Setiap undang-undang tersebut, pengertian seni batik terus mengalami perubahan. Adapun perkembangan pengaturan seni batik di Indonesia adalah sebagai berikut:

a. Pasal 11 ayat (1) huruf f UUHC 1987

Di dalam Penjelasan pasal tersebut, yang dimaksud dengan seni batik adalah seni batik yang bukan tradisional. Sebab seni batik yang tradisional seperti: parang rusak, sidomukti, truntum dan lain-lain, pada dasarnya telah merupakan hasil kebudayaan rakyat yang menjadi milik bersama yang dipelihara dan dilindungi oleh negara.

b. Pasal 11 ayat (1) huruf k UUHC 1997

Di dalam Penjelasan pasal tersebut, yang dimaksud dengan "batik" adalah ciptaan baru atau yang bukan tradisional atau kontemporer. Karya-karya seperti itu memperoleh perlindungan karena mempunyai nilai seni, baik pada ciptaan motif atau gambar maupun komposisi warnanya, sedangkan untuk batik tradisional seperti parang rusak, sidomukti, truntum dan lain-lain menurut perhitungan jangka waktu perlindungan hak ciptanya memang telah berakhir dan menjadi public domein. Bagi orang Indonesia sendiri pada dasarnya bebas untuk menggunakannya.

c. Pasal 12 ayat (1) huruf i UUHC 2002

Di dalam Penjelasan pasal tersebut dinyatakan bahwa batik yang dibuat secara kontemporer dilindungi sebagai bentuk ciptaan tersendiri. Karya-karya seperti itu memperoleh perlindungan karena mempunyai nilai seni, baik pada ciptaan motif atau gambar maupun komposisi warnanya. Disamakan dengan pengertian seni batik adalah karya tradisional lainnya yang merupakan kekayaan bangsa Indonesia yang terdapat di berbagai daerah, seperti seni songket, ikat dan lainlain yang dewasa ini terus dikembangkan.

Berdasarkan ketiga ketentuan di atas dapat diketahui bahwa pada UUHC 1987 dan 1997, seni batik yang mendapat perlindungan hak cipta 
adalah seni batik yang bukan tradisional dengan pertimbangan bahwa seni batik yang tradisional telah menjadi milik bersama (public domein). Konsekuensinya bagi orang Indonesia mempunyai kebebasan untuk menggunakannya tanpa dianggap sebagai suatu pelanggaran. Pada UUHC 2002, unsur yang ditekankan adalah pada "pembuatan batik secara kontemporer". Adapun batik yang dianggap paling baik dan paling tradisional/kontemporer adalah batik tulis. ${ }^{27}$

Menurut Pasal 29 ayat (1) UUHC 2002, sebagai ciptaan yang dilindungi maka pemegang hak cipta seni batik memperoleh perlindungan selama hidupnya dan terus berlangsung hingga 50 tahun setelah meninggal dunia. Selama jangka waktu perlindungan tersebut, pemegang hak cipta seni batik memiliki hak ekslusif untuk melarang pihak lain mengumumkan dan memperbanyak ciptaannya, atau memberi ijin kepada orang lain untuk melakukan pengumuman dan perbanyakan ciptaan yang dipunyai tanpa mengurangi pembatasan-pembatasan menurut peraturan perundangundangan yang berlaku.

Jangka waktu perlindungan tersebut diberikan bagi seni batik yang bukan tradisional, sedangkan bagi seni batik yang tradisional, misalnya parang rusak, truntum, tidak memiliki jangka waktu perlindungan. Hal ini didasarkan pertimbangan bahwa batik tradisional seperti itu diciptakan dan dihasilkan secara turun temurun oleh masyarakat Indonesia sehingga diperkirakan perhitungan jangka waktu perlindungan hak ciptanya telah melewati jangka waktu perlindungan yang ditetapkan dalam undangundang. Karena itu batik tradisional yang ada menjadi milik bersama masyarakat Indonesia (public domein). Selain itu hak cipta batik tradisional yang ada dipegang oleh Negara. Hal ini berarti bahwa negara menjadi wakil bagi seluruh masyarakat Indonesia dalam menguasai kekayaan tradisional yang ada. Perwakilan oleh negara dimaksudkan untuk menghindari sengketa penguasaan atau pemilikan yang mungkin

Ismunandar, R.M., Teknik dan Mutu Batik Tradisional-Mancanegara, (Semarang: Dahara Prize, 1985), halaman 17-18. 
timbul di antara individu atau kelompok masyarakat tertentu. Selain itu penguasaan oleh Negara menjadi penting khususnya apabila terjadi pelanggaran hak cipta atas batik tradisional Indonesia yang dilakukan oleh warga negara asing dari negara lain karena akan menyangkut sistem penyelesaian sengketanya. $^{28}$

Mengacu pada Undang-Undang Hak Cipta, maka ciptaan seni batik mendapat perlindungan hukum karena termasuk dalam lingkup seni, sastra dan ilmu pengetahuan menurut ketentuan Pasal 12 Undang-Undang Hak Cipta. Ciptaan yang ada dalam ketentuan tersebut dilindungi dalam wilayah dalam negeri maupun luar negeri.

Ciptaan batik tradisisonal yang termasuk folklor dilindungi oleh Undang-Undang Hak Cipta, sebagaimana dituangkan dalam ketentuan Pasal 10 ayat (1) dan (2) Undang-Undang Hak Cipta yang menyatakan:

a. Negara memegang hak cipta atas karya peninggalan prasejarah, sejarah dan benda budaya nasional lainnya.

b. Negara memegang hak cipta atas folklor dan hasil kebudayaan rakyat yang menjadikan milik bersama seperti cerita, hikayat, dongeng, legenda, babad, lagu, kerajinan tangan, koreografi, tarian, kaligrafi dan karya seni lainnya.

Hak cipta atas folklore dan hasil kebudayaan rakyat yang menjadi milik bersama, perlindungannya berlaku tanpa batas waktu (Pasal 31 Ayat 1a). Pasal ini jelas bertujuan melindungi karya-karya tradisional.

Walaupun tujuan Pasal 10 ditujukan secara khusus untuk melindungi budaya penduduk asli, akan sulit (barangkali mustahil) bagi masyarakat tradisional untuk menggunakannya demi melindungi karyakarya mereka berdasarkan beberapa alasan, yaitu:

a. Kedudukan pasal 10 UUHC belum jelas penerapannya jika dikaitnya dengan berlakunya pasal-pasal lain dalam UUHC. Misalnya, bagaimana kalau suatu folklore yang dilindungi berdasarkan Pasal 10 ayat (2) tidak bersifat asli sebagaimana disyaratkan Pasal 1 ayat (3)? Undang-undang tidak menjelaskan apakah folklore semacam ini

28 Purba, Afrillyanna, dkk, Op.Cit., halaman 34-35. 
mendapatkan perlindungan hak cipta meskipun merupakan ciptaan tergolong folklore yang keasliannya sulit dicari atau dibuktikan.

b. Suku-suku etnis atau suatu masyarakat tradisional hanya berhak melakukan gugatan terhadap orang-orang asing yang mengeksploitasi karya-karya tradisional tanpa seijin pencipta karya tradisional, melalui negara cq. Instansi terkait.

Undang-undang melindungi kepentingan para pencipta karya tradisional apabila orang asing mendaftarkan di luar negeri. Akan tetapi dalam kenyataan belum ada hasil usaha negara melindungi karya-karya tradisional yang dieksploitasi oleh bukan warga negara Indonesia di luar negeri. Selain itu instansi-instansi terkait yang dimaksud dalam Pasal 10 ayat (3) untuk memberikan ijin kepada orang asing yang akan menggunakan karya-karya tradisional juga belum ditunjuk. ${ }^{29}$

\section{Upaya-upaya Pemerintah Kota Pekalongan menjadikan Batik Pekalongan sebagai komoditas internasional}

Batik dari daerah Pekalongan termasuk batik pesisir yang paling kaya akan warna. Sebagaimana ciri khas batik pesisir, ragam hiasnya bersifat naturalistis. Dari sekian batik pesisir, batik dari daerah Pekalongan inilah yang sangat dipengaruhi selera sera gaya para pendatang keturunan Cina dan Belanda.

Menurut gaya dan seleranya, serta dilihat dari segi ragam hiasnya maupu tata warnanya, batik daerah Pekalongan dapat digolongkan menjadi tiga golongan, yaitu:

1. Batik Encim yang dikenal dengan tata warna khas Cina dan sering mengingatkan pada benda-benda porselin Cina. Batik Encim Pekalongan tampaknya condong pada tata warna porselin famille rose, famille verte dan sebagainya. Ragam hiasnya bisa digolongkan:

a. Ragam Hias Buketan, yang biasanya memiliki tata warna famille rose, famille verte dan sebagainya.

Ibid, halaman 266-267. 
b. Ragam Hiasa Simbolis Kebudayaan Cina dengan motif seperti burung hong (kebahagiaan), naga (kesiagaan), banji (kehidupan abadi), kilin (kekuasaan), kupu-kupu dan lain-lain.

c. Ragam Hias yang bercorak lukisan seperti arakan pengantin Cina. Ada pula ragam hias yang diilhami cerita/dongeng berasal dari kebudayaan Cina.

2. Kain Batik Pekalongan yang bergaya dan berselerakan belanda, antara lain yang sangat terkenal adalah batik van Zuylen.

Kebanyakan batik yang bergaya Belanda ini umumnya merupakan kain sarung, hal ini dikarenakan lebih mudah pemakaiannya bagi kaum pendatang. Dalam kelompok batik ini terlihat ragam hias buketan yang biasanya terdiri dari flora yang tumbuh di negeri Belanda seperti bunga Krisan, buah anggur dan rangkaian bunga gaya Eropa. Dikenal pula batik dengan ragam hias kartu bridge, lambang bagi masyarakat Eropa seperti cupido (lambang cinta), tapak kuda dan klaverblad (lambang pembawa keberuntungan). Terdapat pula ragam hias yang didasarkan cerita/dongeng Barat seperti Putri salju, Cinderella dan Si Topi Merah. Sedangkan yang dinamakan ragam hias kompeni adalah ragam hias berupa lukisan barisan serdadu Belanda dan benteng Belanda.

3. Batik yang berselerakan Pribumi. Batik bergaya pribumi ini umumnya sangat cerah dan meriah dalam tata warnanya. Tak jarang pada sehelai kain batik dijumpai delapan warna yang snagat berani, tetapi snagat menakjubkan serta secara keseluruhan sangat menarik. Ragam hiasanya sangat bebas, meskipun disini banyak terlihat ragam hias tradisonal dari Solo-Yogyakarta seperti ragam hias lar, parang, meru dan lain-lain yang telah mengalami sedikit perubahan dalam gayanya. ${ }^{30}$

Pemerintah Kota Pekalongan telah mengeluarkan SK Walikota Pekalongan Nomor 530/216 Tahun 2002 tentang Produk Unggulan Daerah

${ }^{30}$ Djoemena, Nian S., Op. Cit., halaman 59-61. 
Kota Pekalongan yang merumuskan bahwa produk unggulan daerah Kota Pekalongan berupa enam komoditas produk unggulan yaitu:

1. Komoditas Batik;

2. Komoditas Konvekasi;

3. Komoditas Pertenunan Alat tenun Bukan Mesin (ATBM);

4. Komoditas Kerajinan Enceng Gondok dan Serat Alam;

5. Komoditas Pertenunan Alat Tenun Mesin; dan

6. Komoditas Pengolahan Ikan..

Agar batik Pekalongan dapat bertahan dalam menghadapi persaingan batik yang semakin besar saat ini, baik yang berasal dari daerah lain maupun dari negara tetangga, maka perlu adanya upaya-upaya dari Pemerintah Kota Pekalongan dalam meningkatkan kualitas produk serta dalam mengembangkan pemasarannya. Upaya yang telah dilakukan Pemerintah Kota Pekalongan berkaitan dnegan peningkatan kualitas dan pemasaran produk batik Pekalongan antara lain:

1. Dilakukan kegiatan-kegiatan promosi yaitu:

a. Pemerintah Kota menetapkan pakaian batik sebagai pakaian seragam pada hari Kamis dan Sabtu.

b. Setiap tahun mengikutsertakan pengusaha/pengrajin batik dalam event-event ekspo/ pameran produk unggulan.

c. Melakukan kontak dagang.

2. Peresmian Trading House UKMK Kota Pekalongan pada tanggal 3 Mei 2003 yang merupakan wadah UKM dalam mengembangkan pemasaran.

3. Pembukaan Pusat Perkulakan Batik di ITC Cempaka Masa Jakarta dan Pusat Perkulakan Batik di Pasar Sunan Giri Rawamangun Jakarta.

4. Peningkatan SDM melalui kursus/pelatihan bagi pengusaha/pengrajin batik Kota Pekalongan.

5. Pemberian kredit dari Aggaran Pendapatan dan Pengeluaran Daerah (APBD) sebagai bantuan modal kepada Usaha Kecil Menengah (UKM). 
6. Mendukung dibangunnya sentra-sentra grosir di Kota Pekalongan.

7. Menetapkan 96 motif batik untuk disahkan menjadi hak cipta.

Peranan Pemerintah Kota Pekalongan dalam pengembangan batik pada masa mendatang antara lain:

1. Mengembangkan potensi batik dengan formulasi yang lebih fokus dan terkonsentrasi melalui pendekatan kluster industri. Dalam pengembangan ini terdapat keterkaitan antara sentra produksi dan sentra perdagangan. Kondisi sentra dideskripsikan sebagai berikut:

a. Sentra Produksi

1) Kampung Pusat Produksi Tenun ATBM dan Batik di Medono;

2) Kampung Pusat Produksi Batik di Jenggot;

3) Kampung Pusat Produksi Serat Alam di Kecamatan Pekalongan Utara.

b. Sentra Perdagangan

1) Pasar Grosir Batik Sentono;

2) Pasar Grosir Gamer;

3) Mega Grosir.

2. Klinik Hak Kekayaan Intelektual

3. Bisnis Centre merupakan pusat informasi perdagangan.

4. Tera Ulang

5. Musium Batik

6. Mendukung berdirinya Politeknik Pusmanu Pekalongan agar lebih berkembang.

7. Mengusahakan pemberian kredit lunak kepada pengrajin.

8. Peningkatan SDM. ${ }^{31}$

31 Wahyu dan Slamet, Klinik Bisnis, Dinas Perindustrian, Perdagangan dan Koperasi Kota Pekalongan, 29 Maret 2008.A 


\section{PENUTUP}

\section{a. Simpulan}

1. Seni batik di Indonesia mulai mendapat perlindungan Hak Cipta sejak UUHC 1987 hingga UUHC 2002. Menurut UUHC 1987 dan UUHC 1997, seni batik yang mendapat perlindungan adalah seni batik yang bukan tradisional dengan pertimbangan batik yang tradisional telah menjadi milik bersama, sehingga konsekuensinya bagi orang Indoonesia mempunyai kebebasan untuk menggunakannya tanpa dianggap sebagai suatu pelanggaran. Sedangkan UUHC 2002, unsur yang ditekankan adalah pada pembuatan batik secara kontemporer. Seni batik mendapat perlindungan hukum karena termasuk dalam lingkup Hak Cipta menurut ketentuan Pasal 12 UUHC 2002. dan untuk ciptaan batik tradisional yang termasuk folklor dilindungi oleh UUHC 2002 Pasal 10.

2. Upaya-upaya Pemerintah Kota Pekalongan menjadikan batik Pekalongan sebagai komoditas internasional adalah sebagai berikut:

a. Mengembangkan potensi batik dengan formulasi yang lebih fokus dan terkonsentrasi melalui pendekatan kluster industri (sentra produksi dan sentra perdagangan)

b. Klinik Bisnis dan Hak Kekayaan Intelektual

c. Musium Batik Pekalongan

d. Mengusahakan pemberian kredit lunak kepada pengrajin untuk meningkatkan permodalan sehingga keuntungan dapat dinikmati pengrajin/pengusaha. 
e. Peningkatan SDM terutama untuk pengrajin dengan kursus-kursus pelatihan

f. Pembangunan sentra-sentra grosir; .

\section{b. Rekomendasi}

\section{Aspek Hukum}

a. Pemerintah Kota Pekalongan segera mengeluarkan peraturan-peraturan mengenai Batik sebagai lingkup Hak Kekayaan Intelektual yang perlu dilindungi dan dilestarikan, hal ini berkaitan dengan batik sebagai produk unggulan Kota Pekalongan, sehingga diharapkan dengan adanya kebijakan Pemerintah Kota Pekalongan akan tercipta iklim yang kondusif pada dunia usaha perbatikan dan sebagai peraturan pelaksana Undang-undang Nomor 19 Tahun 2002 tentang Hak Cipta khususnya Seni Batik.

b. Dengan dikeluarkannya Peraturan Menteri Perindustrian Republik Indonesia Nomor : 74/M-IND/per/9/2007 tentang Penggunaan Batikmark "batik INDONESIA" pada Batik Buatan Indonesia, tertanggal 18 September 2007 diharapkan Pemerintah Kota Pekalongan dapat melaksanakan peraturan tersebut sehingga mempermudah masyarakat Indonesia dan asing mengenali batik buatan Indonesia dan terlindungi dari adanya tindakan peniruan atau penjiplakan motif batik Pekalongan. 


\section{Aspek Non Hukum}

a. Masih diperlukan sosialisasi Hak Kekayaan Intelektual khususnya tentang Hak Cipta kepada para pengrajin dan pengusaha batik baik Perusahaan maupun UKM/IKM, sehingga kesadaran untuk mendaftarkan batik melalui Hak Cipta, Merek, Desain Industri atau Paten meningkat, hal ini mengingat batik sebagai aset daerah Kota Pekalongan.

b. Diperlukan banyak sumber daya manusia yang mempunyai keahlian dan pengalaman di bidang Hak Kekayaan Intelektual.

c. Membentuk Komite Kerja Sama untuk mendata, mengklasifikasi dan mendaftarkan karya-karya yang sudah menjadi public domein.

d. Mengembangkan Musium Batik Pekalongan yang bertaraf internasional dengan membuat website yang mempromosikan Kota Pekalongan sebagai Kota Batik.

\section{DAFTAR PUSTAKA}

Ahmad, Basyir, Batik Tingkatkan Ekonomi Warga, Suara Merdeka, 1 September 2007.

Arthur, John \& William H. Shaw, (ed), Readings in the Philosophy of law, $2^{\text {nd }}$ edition, Prentic Hall, New jersey, 1993, halaman 73 dikutip dari Purba, Afrillyanna, dkk, TRIPs-WTO dan Hukum Hak Kekayaan Inteklektual Indonesia, Kajian Perlindungan Hak Cipta Seni Batik Tradisional Indonesia, (Jakarta: Rineka Cipta, 2005). 
Audah, Husain, Hak Cipta \& Karya Cipta Musik, (Jakarta; Pustaka Litera Antar Nusa, 2003).

Ayu, Miranda Risang, Hak Moral, Indikasi Asal dan Hak Kebudayaan, Opini, Pikiran Rakyat, 4 Desember 2007.

Badrulzaman, Mariam Darus, Mencari Sistem Hukum Benda Nasional, (Alumni: Bandung, 1997).

D.A. Candraningrum, Sohirin, Ruwetnya Mendaftar Warisan Budaya, Tempo, 18 November 2007.

Damayanti, Lelita, Laporan Kegiatan Pelaksanaan Pekan Batik Internasional 2007 Kota Pekalongan 1-5 September 2007 Kawasan Jalan Jetayu oleh Panitia PBI 2007 Pemerintah Kota Pekalongan.

Damian, Eddy, Hukum Hak Cipta, (Bandung: Alumni, 2005).

Damian, Eddy, dkk, Hak Kekayaan Intelektual Suatu Pengantar, (Asian Law Group Pty Ltd bekerja sama dengan Alumni, Bandung, 2002).

Djoemena, Nian S., Ungkapan Sehelai Batik (Its Mystery and Meaning), (Jakarta: Djambatan, 1986).

Djumhana, Muhamad dan R. Djubaedillah, Hak Milik Intelektual (Sejarah, Teori dan Praktiknya di Indonesia), (Bandung: Citra Aditya Bakti, 1997).

Diskusi Batik Tradisional : Batik Perlu Dimasukkan dalam Kurikulum Sekolah, Majalah Batik Sekar Jagad, No.5/Th II, November 2001.

Ismunandar, RM., Teknik dan Mutu Batik Tradisional-Mancanegara, (Semarang: Dahara Prize, 1985).

Jaya, Nyoman Serikat Putra, Penegakan Hukum Pidana di Bidang Hak atas Kekayaan Intelektual, disampaikan sebagai bahan mata kuliah di Magister Ilmu Hukum Univ. Diponegoro, Semarang, 2007.

Junus, Emawati, Perlindungan Hukum Hak Kekayaan Intelektual, Traditional Knowledge, dan Folklor, Temu Wicara Perlindungan Hukum Folklor dan Traditional Knowledge, (Jakarta: 13 Agustus 2003).

Leaffer, Marshall, Understanding Copyright Law, Matthew Bender \& Company Incorporated, New york, 1998, halaman 14 dikutip dari Purba, Afrillyanna, dkk, TRIPs-WTO dan Hukum Hak Kekayaan Inteklektual Indonesia, Kajian Perlindungan Hak Cipta Seni Batik Tradisional Indonesia, (Jakarta: Rineka Cipta, 2005). 
Lindsey, Tim dkk, Hak Kekayaan Intelektual Suatu Pengantar, (Bandung: Alumni, 2006).

Maryadi, Transformasi Budaya, (Surakarta: Press, 2000), halaman 53, dikutip dari Riswandi, Budi Agus.

Nasution, S. dan M. Thomas, Buku Penuntun Membuat Tesis, Skripsi, Disertasi dan Makalah, (Bandung: Jemmars, 1988).

Purba, Achmad Zen Umar, Jembatan Budaya Serumpun, (Jakarta: Tempo, 18 November 2007).

Purba, Afrillyanna, TRIPs-WTO dan Hukum Hak Kekayaan Inteklektual Indonesia, Kajian Perlindungan Hak Cipta Seni Batik Tradisional Indonesia, (Jakarta: Rineka Cipta, 2005).

Purwadi, Trias, Museum, Pasar Grosir dan Kampung Batik, (Semarang: Suara Merdeka, 1 September 2007).

-------, Menduniakan Batik Lewat Pekalongan, (Semarang: Suara Merdeka, 3 September 2007).

---------, Kauman Cikal Bakal Pembatik, (Semarang: Suara Merdeka, 1 Septmber 2007).

Rahardjo, Satjipto, Ilmu Hukum, (Bandung: Alumni, 1986).

Riswandi, Budi Agus dan M. Syamsudin, Hak Kekayaan Intelektual dan Budaya Hukum, (Jakarta: Raja Grafindo Persada, 2004).

Saleh, Ismail, Hukum dan Ekonomi, (Jakarta: Gramedia Pustaka Utama, 1990).

Santoso, Budi, Hak Cipta, Makalah disampaikan pada Pelatihan Hukum Bisnis dan HKI di Universitas Diponegoro, Semarang, tanggal 25 Juli 2006.

Soekanto, Soerjono dan Sri Mamudji, Penelitian Hukum Normatif Suatu Tinjauan Singkat, (Jakarta: Raja Grafindo Persada, 2001).

Soemitro, Ronny Hanitijo, Metode Penelitian Hukum dan Jurimetri, (Jakarta: Ghalia Indonesia, 1983).

S. Nasution dan M. Thomas, Buku Penuntun Membuat Tesis, Skripsi, Disertasi, dan Makalah, (Bandung: Jemmars, 1988). 
Suhardo, Etty S., Implikasi Undang-undang Nomor 19 Tahun 2002 bagi Pengguna Hak cipta, Makalah disampaikan pada Seminar Nasional Menyikapi Problema Hak Cipta dalam Dunia Usaha : Implementasi Undang-undang Nomor 19 Tahun 2002 , diselenggarakan oleh Fakultas Hukum, Universitas Diponegoro, Semarang, 11 Desember 2003.

Suyanto, A.N., Sejarah Batik Yogyakarta, (Yogyakarta: Merapi, 2002).

Usman, Rachmadi, Hukum Hak atas Kekayaan Intekektual "Perlindungan dan Dimensi Hukumnya di Indonesia, (Bandung: Alumni, 2003).

Warassih, Esmi, Pranata Hukum Sebuah Telaah Sosiologis, (Suryandaru Utama: Semarang, 2005).

\section{Peraturan-peraturan :}

1. Ketentuan Internasional

Konvensi Bern 1886 tentang Perlindungan Karya Sastra dan Seni

Konvensi Hak Cipta Universal 1955

Perjanjian Umum mengenai Tarif dan Perdagangan (The General Agreement on Tariffs and Trade (GATT)) yang mencakup perjanjian internasional mengenai Aspek-aspek yang dikaitkan dengan Perdagangan dari HKI (Agreement on Trade Related Aspects of Intellectual Property Rights (TRIPs)) 1994.

2. Peraturan Perundang-undangan Nasional

Undang-undang Nomor 6 Tahun 1982 Tentang Hak Cipta.

Undang-undang Nomor 7 Tahun 1987 Tentang Perubahan atas Undangundang Nomor 6 Tahun 1982 Tentang Hak Cipta.

Undang-undang Nomor 12 Tahun 1997 Tentang Perubahan atas Undangundang Nomor 6 Tahun 1982 Tentang Hak Cipta sebagaimana telah diubah dengan Undang-undang Nomor 7 Tahun 1987.

Undang-undang Nomor 19 Tahun 2002 Tentang Hak Cipta. 


\section{Website:}

http://wikipediaindonesia.com.

www.yahoo.com "Sejarah Batik di Indonesia".

$\underline{\text { www.batikmarkets.com }}$ "Pekalongan Kota Batik".

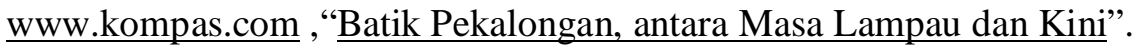

http://www.wikipedia.org/wiki/batik.id ,"Batik".

www. Indoartssf.com.

$\underline{\text { www.liputan6.com.Pekalongan }}$

www.storyofbatik.com

http://www.grosirpekalongan.com/jenisbatik.html 